\title{
The Effects of Person-Organisation Fit and Employee Commitment. The Mediating Role of Organisational Culture.
}

\author{
Maxwell Fobi Kontor \\ TonyMax Research and Development Consult
}

\begin{abstract}
The concept of organizational culture is significant in the study of organizational behaviour and has increasingly become a vital area of interest in academic research. Organization culture recognizes the contributions of the employees in an organization, and provides holistic understanding of what is to be achieved, how goals are interrelated, and how each employee could attain organizational goals. Organizational culture is an important factor used to determine how well an employee fits into their organizational context, and it has been asserted that a good fit between the employee and their organization is vital for organisational success. The main purpose of the study was to examine the effects of organisational culture on person organisation fit and employee commitment. Simple random sampling technique was adopted to gather responses from the respondents. The study revealed that organisational culture has a positive and significant effect on person organisation - fit and employee commitment. Moreover, it was identified that organisational culture fully mediates on person organisation-fit. Based on this, the study recommended that organizational policies regarding culture should be clear for understanding by the employees. Along this line, organization should have a flexible culture and top management should use decentralized technique of management so that employees at low level have authority and power to make decision regarding problem they encounter at their level of authority.
\end{abstract}

Keywords: Commitment, Person Organisation Fit, Organisational Culture, Mediation

\section{INTRODUCTION}

It is indispensable for an organization to establish an organizational culture to maintain its position in the business environment (Habib, Aslam, Hussain, Yasmeen, \& Ibrahim, 2014). Organizational culture must be developed in order to provide support to an organization and bring continuous improvement. The culture of an organization is substantial for the development of an organization because it impacts on employee commitment, retention and job satisfaction (Lund, 2003). When the culture of an organization is flexible, working environment becomes conducive for employees to work easily and independently without feeling any burden (Habib et al., 2014). Organizational culture is an effective tool that helps an organization to quantify business function (Gray, Densten, \& Sarros, 2003). In this regard, organizations need to build up their culture for the survival in the competitive market (Sabir, Razzaq, \& Yameen, 2010). In our contemporary era of competition and innovation, organizations need such culture that increases the employee commitment and satisfaction at the work environment (Dwinfour, Adam, \& Adom, 2017). The concept of organizational culture has been significant in the study of organizational behaviour due to its significance in enhancing organizations' capabilities and how they function (Nazir, 2005; Silverthorne, 2004). Organizational culture is thus linked with the disposition of the organization, depicting employee behaviour. The culture of an organization is an important factor used to determine how well an employee fits into their organizational context, and it has been asserted that a good fit between the employee and their organization is vital for organisational success (Nazir, 2005). Moreover, the culture of an organizational affects the commitment of employees, and has accentuated that the strength of organizational culture is associated with higher levels of 
employee commitment (Acar, 2012). It is usually understood that a strong culture is synonymous with consistency, and therefore, the management of culture can be treated as the management of commitment (Habib et al., 2014). Clugston (2000), and Wasti (2003), emphasized that corporate culture wields a substantial effect on behaviour of employees, particularly commitment and retention. Given the importance of organizational culture and its influence on organizational behaviour, it is critical that contemporary organizations also consider organization culture's importance on their employee commitment and personorganisation fit. It has been shown that organisational culture could influences commitment (Sharma \& Singh, 2017). Commitment is a fundamental variable of interest in organizational studies with a plethora of studies seeking to explicate its causal antecedents (Rastegar \& Aghayan, 2012). Lau \& Idris (2001), opined that employee commitment is influenced by corporate culture since it reflects the relative strength of employees' attachment or involvement with their organization. According to Meyer, Stanley, Herscovitch, \& Topolnytsky (2002), commitment of employees may be increased by changing the organizational culture in the direction of person-organization fit. The notion of person-organization fit (P-O fit) is concerned with identifying the antecedents and consequences of compatibility between employees and the organizations in which they work (Karakurum, 2005). P-0 fit has demonstrated significant relationships with employee outcomes employee commitment, job satisfaction and performance. However, P-O fit takes place when the organization fulfils employee's needs (Sutarjo, 2011). In view of the significance of employees' commitment and person-organisation fit in contributing to organisational success, the study assessed the effect of organisational culture on person-organisation fit and employees' commitment. Thus, the study sought to examine the effects of organisational culture on employees' commitment and person-organisation fit in Rural Banks in Kumasi.

There have been plethora of studies conducted on organisational culture, person-organisation fit and employee commitment. Studies conducted have concentrated on person-organisation fit and its influence on job satisfaction, work engagement, commitment and turn over intentions (Ahmadian \& Etebarian, 2015; Karakurum, 2005; Latif \& Bashir, 2013). Most of the studies conducted in this area failed to analyse the relationships of the three variables (organisational culture, person-organisation fit and employee commitment) especially by moderating and mediating some of the variables. There exists a limited knowledge on the role of organisational culture on person-organisation fit and employees' commitment (Lok \& Crawford, 2001), especially at the banking sector. In addition to this, there is contradiction on the exact impact of organizational culture on employee commitment (Rastegar \& Aghayan, 2012). In this regard there is the need to conduct further research to fill the gap by either validating existing literature or contribute new knowledge in the existing literature. Moreover, there is a limited knowledge on the mediating role of organisational culture on the effect of person-organisation fit and employees' commitment, specifically in the banking sector. Banking institutions are increasingly devising strategies to ensure employees commitment and person-organisation fit. In this regard, the study sought to assess the effects of organisational culture on personorganisational fit and employees' commitment.

\section{LITERATURE REVIEW}

\section{Concept of Organisational Culture}

The concept of organizational culture has been significant in the study of organizational behaviour and has become a major area of interest in academic research (Nazir, 2005; Silverthorne, 2004). Organizational culture is imperative in determining how well an employee fits into their organizational context. Organizational culture is generally defined as the normative glue that holds an organization together. Organizational culture refers to the set of 
values, beliefs and behaviour patterns that shapes employee's behaviour and forms the core identity of the organization (Lund, 2003). The cultural pattern comprises various beliefs, values, and symbols that govern the operating style of the people within an organisation (Narayana, 2017). In light of this, organizational culture could be described as a system of common values which we can estimate that employees accept the similar organization culture even with different background within the organization.

These indicates that organizational culture could be the means of keeping employees in line and exhilarating them towards organizational objectives. Lok \& Crawford (2001), opined that when employees are more enthused with the culture of an organization, job satisfaction and performance of employees tend to be increase. The flexibility of the culture of an organisation provide a conducive working environment to employees (Habib et al., 2014). Premising on these, organizational culture could be seen as the internal integration and coordination between a firm's operations and its employees. Harrison et al. (1992), indicates four dimensions of organizational culture. According to them the dimensions of organizational culture consist of role dimension, power dimension, achievement dimension and support dimension. Role dimension is basically job description and specialization. The power dimension concentrates on inequality of access to redemption. Achievement dimension hinges on task which concentrates on realizing organizational goals. The support dimension describes an organizational climate that is based on neutral trust between the individual and the organization.

\section{Concept of Employee Commitment}

Commitment has been a central focus in organizational studies over decades (Clugston, 2000). Employees' commitment is the willingness of employees to accept the goals and values of the organization and work towards achieving them (Muthuvelo \& Che Rose, 2005). Ongori (2007), described employee commitment as an affective response to the whole organization and the degree of attachment or loyalty employees feel towards the organization. According to (Janićijević, 2015), employees' commitment is seen as a certain expansion and a higher degree of job satisfaction, where employees feel a deep attachment to an organization. Employee commitment is important and plat crucial role in organizational success. Strong commitment is correlated with organizational citizenship, job satisfaction, job performance and employee retention (Ćulibrk, Delić, Mitrović, \& Ćulibrk, 2018; Hafiz, 2017; Quratulain, Khan, Crawshaw, Arain, \& Hameed, 2018). According to Lok \& Crawford (2001), employees' commitment is viewed from behavioural and attitudinal perspectives.

Meyer et al. (1991), identified three types of commitment. The types of commitment comprise of affective commitment, continuance commitment and normative commitment. Affective commitment involves an emotional attachment to, involvement in, and identification with one's organization, which are based on a desire to belong (Samudi, Slambolchi, \& Mobarakabadi, 2016). Affective commitment arises from the perception of positive social exchanges between the employee and organization. Also, normative commitment refers to employee's feeling of obligation to remain with the organization (Rastegar \& Aghayan, 2012). Continuance commitment is derived from the perceived costs of leaving, including the loss of desired investments and few job alternatives.

\section{Person-Organisation Fit (P-0 Fit)}

In recent years, person-organization (P-O) fit has been an area of interest which focused largely on the antecedents and consequences of compatibility between people and the organizations in which they work (Karakurum, 2005). Person-Organization fit (P-O fit) is defined as the compatibility between people and organizations that occurs when at least one 
entity provides what the other needs or they share similar fundamental characteristics or both (Kristof-Brown, Zimmerman, \& Johnson, 2005). The fit between employees'/individuals and organization is related to numerous behavioural outcomes such as job satisfaction, employee commitment, retention, and performance (Boon, den Hartog, Boselie, \& Paauwe, 2011; Wheeler, Gallagher, Brouer, \& Sablynski, 2007). Therefore, organizations prefer to work with employees whose values match the values of organizations.

\section{Relationship between Organisational Culture and Employee Commitment}

Corporate culture is vital in developing and sustaining employee commitment (Silverthorne, 2004). Shared values which is an aspect of corporate culture enhance employees' identification and attachment to the organization. This clearly shows that employees choose to be committed to organizations whose values they share. Lau \& Idris (2001), found that organizational commitment is influenced by corporate culture because it reflects the relative strength of employees' attachment or involvement with their organization. Nazir (2005), argued that the strength of organizational commitment is influenced by the level of organizational culture. Strong corporate culture enables employees understand and works towards the attainment of organization goals When employees work towards organizational goals, their level of commitment increases (Nongo \& Ikyanyon, 2012). Based on this, the study hypothesized that; Hypothesis 1: There is a significant and positive relationship between organisational culture and employee commitment.

\section{Relationship Between Organisational Culture (OC) and Person Organisation-Fit (POF)}

The idea of organisational culture has been identified as an important aspect of organisational behaviour and as concept that is useful in helping to understand how organisation function. Schein (2010), theorized that organizational culture might be an important factor in determining how well an individual assimilates into an organization. The key premise of person organisation-fit is that employees whose values align well with their organization's values will be satisfied and will stay and contribute to the organization and vice-versa. Organizational culture is an important factor used to determine how well an employee fits into their organizational context (Nazir, 2005). More precisely, it is demonstrated that a major outcome of the organisation culture is linked to person organisation-fit (Sutarjo, 2011). When the individual values align with that of the organisation, the level of compatibility between the employee and the employer will rise. Thus, positive organisational culture is an important determinant of person organisation-fit. Premising on this, the study proposed that;

\section{Hypothesis 2: There is a significant and positive relationship between organizational} culture and person organisation-fit

\section{Mediating Role of Organisational Culture on Person Organisation-Fit and Employee Commitment}

Organizational commitment is described as 'one's emotional attachment to, identification with, and involvement in a particular organization. In line with this, a committed person identifies with the values and goals of the organisation, implying that there is an association between value congruency (person-organisation fit) and organisational commitment. Two metaanalytic reviews concluded that $\mathrm{P}-\mathrm{O}$ fit, particularly value fit, relates positively to commitment and intention to stay (Kristof-Brown et al., 2005; Verquer, Beehr, \& Wagner, 2003). Harris \& Mossholder (1996), found that congruence between employees' perceptions of the organization's culture and their ideal culture was generally associated with higher levels of commitment. Ostroff, Shin, \& Kinicki (2005), hypothesized that a good fit between an employee's personal values and his/her perceptions of the organization's values would be associated with stronger commitment, and that a mismatch in either direction would be 
accompanied by lower commitment. However, it is contested in the study that, person organization fit does not influence the outcome of employee commitment alone. There may be an equally important variable that mediate the relationship. Based on this, the study hypothesized that:

\section{Hypothesis 3: Organizational culture mediates the relationship between person organization-fit and employee commitment.}

\section{METHODOLOGY}

This study employed quantitative method to analyse the mediating role of organisational culture on person organization fit and employee commitment at the banking sector. The quantitative method was operationalised to answer the research questions by collecting, analysing and integrating the quantitative data of the study. The study population consist of employees and managers of rural banks in Kumasi. The simple random sampling technique was used to gather responses from 104 workers in rural banks in Kumasi. This method allows each individual to be selected randomly and entirely by chance, such that each person has the same probability of being chosen at any stage during the sampling process. The data received from respondents was edited to correct errors and omissions that took place for the purpose of ensuring consistency. Analysis of the data was done using both descriptive statistics and inferential analysis (regression analysis). The regression and correlation analysis were used to test the hypothesis of the study.

\section{Reliability}

To check the reliability of the scale and internal consistency of the measure, the Cronbach's Alpha method was used. The reliability of the organisational culture scale was .712, Person Organisation Fit is .704 and Commitment is .828 (See Table 1). Cronbach alpha values greater than 0.7 indicates high reliability. This implies that the reliability of the research instruments was high.

Table 1: Reliability of Constructs

\begin{tabular}{|l|l|}
\hline Item & Cronbach alpha value \\
\hline Organisational culture (17 items) & .712 \\
\hline Person Organisation Fit (11 items) & .704 \\
\hline Commitment (18 items) & .828 \\
\hline
\end{tabular}

\section{Confirmatory Factor Analysis}

Structural Equation Modelling is a powerful quantitative data analytical technique which estimates and tests theoretical relationships between/among latent and/or observed variables. It has been suggested that there is no consistent standard for evaluating an acceptable model (Kline, 2011). IFI, TLI, CFI, RMSEA, CFI and TLI are considered as fit measures (Ullman \& Bentler, 1998). A subset or sample of fit indices from major categories has been reported in this study to assess the degree of overall fitness of the measurement model. The $\chi 2 / \mathrm{df}$ (CMIN/DF), CFI, and RMSEA, Average Variance Extracted (AVE) and Construct Reliability (CR) are considered in this study. The RMSEA value of about 0.05 or less would indicate a close fit of the model in relation to the degrees of freedom. The CFI value is between 0 and 1 . A value close to 1 indicates a very good fit. A normed chi-square (CMIN/DF) value close to 1 and not exceeding 3 indicates a good fit. Average Variance Expected (AVE) value greater than .05 is acceptable. Modification and standardised loadings (standardised regression weights) in AMOS output were the options to verify the dimensionality of the measurement or to verify the model fit. The result of the confirmatory factor analysis is indicated in Table 2 . The results indicated that most values fall within the acceptable values. 
Table 2: Confirmatory Factor Analysis

\begin{tabular}{|c|c|c|c|c|c|}
\hline \multicolumn{6}{|c|}{ Organisational Culture } \\
\hline & $\begin{array}{c}\text { CMIN/DF } \\
(\chi 2 / d f)\end{array}$ & CFI & RMSEA & AVE & CR \\
\hline Initial & 4.710 & .629 & .190 & \multirow[t]{2}{*}{0.26} & \multirow[t]{2}{*}{0.73} \\
\hline Final & 2.012 & .820 & .098 & & \\
\hline \multicolumn{6}{|c|}{ Person Organisation-Fit } \\
\hline Initial & 3.165 & 690 & .143 & \multirow[t]{2}{*}{0.22} & \multirow[t]{2}{*}{0.77} \\
\hline Final & 1.599 & 895 & .075 & & \\
\hline \multicolumn{6}{|c|}{ Commitment } \\
\hline Initial & 1.217 & .996 & .045 & \multirow[t]{2}{*}{0.62} & \multirow[t]{2}{*}{0.33} \\
\hline Final & .665 & 1.000 & .000 & & \\
\hline
\end{tabular}

\section{RESULTS}

\section{Effect of Organisational Culture on Employee Commitment}

A regression analysis was conducted to test for relationship between organisational culture and employee commitment. The results indicated in Table 3 shows that there is a significant relationship between organisational culture and employee commitment. There is a significant relationship because the $\mathrm{p}$ value $(.001)$ is less than $.05(\mathrm{p}<.05)$. Moreover, the relationship is positive because the beta value is positive $(\beta=.337)$. This implies that when organisational culture is high, employee commitment will also rise. Thus, hypothesis 1 which states that organizational culture has a significant and positive effect on employee commitment is supported.

Table 3: Regression on the Effect of Organisational Culture on Employee Commitment

\begin{tabular}{|c|c|c|c|c|c|c|c|}
\hline \multicolumn{8}{|c|}{ Model Summary } \\
\hline Model & $\mathrm{R}$ & R Square & \multicolumn{2}{|c|}{ Adjusted R Square } & \multicolumn{3}{|c|}{ Std. Error of the Estimate } \\
\hline 1 & $.333^{a}$ & .111 & \multicolumn{2}{|l|}{.102} & \multicolumn{3}{|c|}{.42236} \\
\hline \multicolumn{8}{|c|}{ Coefficient } \\
\hline \multicolumn{8}{|c|}{ a. Predictors: (Constant), Organisational Culture } \\
\hline \multirow{2}{*}{\multicolumn{2}{|c|}{ Model }} & \multicolumn{2}{|c|}{ Unstandardized Coefficients } & \multirow{2}{*}{\multicolumn{2}{|c|}{$\begin{array}{c}\begin{array}{c}\text { Standardized } \\
\text { Coefficients }\end{array} \\
\text { Beta }\end{array}$}} & \multirow[t]{2}{*}{$\mathrm{t}$} & \multirow[t]{2}{*}{ Sig. } \\
\hline & & $\mathrm{B}$ & Std. Error & & & & \\
\hline \multirow{2}{*}{ c } & \multirow{2}{*}{ (Constant) } & .845 & .126 & & & 6.708 & .000 \\
\hline & & .337 & .094 & \multicolumn{2}{|c|}{.333} & 3.564 & $\begin{array}{l}.001 \\
\end{array}$ \\
\hline
\end{tabular}

\section{Effect of Organisational Culture and Person Organisation-Fit}

A regression analysis was used to assess the effect of organisational culture on person organisation-fit. The results show that there is a significant relationship between organisational culture and person-organisation fit $(\mathrm{p}<.05)$. The relationship is positive because of the beta value $(\beta=.380)$. The $R$ square of .202 shows that approximately $20.2 \%$ of the variations in organizational culture is predicted by person organization-fit while the remaining $(79.8 \%)$ is explained by other factors (See Table 4 ). 
Table 4: Regression on the Effect of Organisational Culture on Person-Organisation-fit

\begin{tabular}{|c|c|c|c|c|c|c|c|}
\hline \multicolumn{8}{|c|}{ Model Summary } \\
\hline Model & $\mathrm{R}$ & R Square & \multicolumn{2}{|c|}{ Adjusted R Square } & \multicolumn{3}{|c|}{ Std. Error of the Estimate } \\
\hline 1 & $.450^{\mathrm{a}}$ & .202 & \multicolumn{2}{|c|}{.195} & \multicolumn{3}{|c|}{.33346} \\
\hline \multicolumn{8}{|c|}{ a. Predictors: (Constant), Organisational Culture } \\
\hline \multicolumn{8}{|c|}{ Coefficients $^{\mathbf{a}}$} \\
\hline \multirow{2}{*}{\multicolumn{2}{|c|}{ Model }} & \multicolumn{2}{|c|}{ Unstandardized Coefficients } & \multirow{2}{*}{\multicolumn{2}{|c|}{$\begin{array}{c}\begin{array}{c}\text { Standardized } \\
\text { Coefficients }\end{array} \\
\text { Beta } \\
\end{array}$}} & \multirow[t]{2}{*}{$\mathrm{t}$} & \multirow[t]{2}{*}{ Sig. } \\
\hline & & B & Std. Error & & & & \\
\hline \multirow{2}{*}{1} & (Constant) & .685 & .099 & \multirow{2}{*}{\multicolumn{2}{|c|}{.450}} & 6.891 & .000 \\
\hline & Organisational Culture & .380 & .075 & & & 5.088 & .000 \\
\hline
\end{tabular}

\section{Mediating Role of Organisational Culture on Person Organisation-Fit and Employee Commitment}

The general test for mediation is to examine the relation between the predictor and the dependent variable, the relation between the predictor and the mediator variable, and the relation between the mediator and the criterion/dependent variables. All of these correlations should be significant.

The steps suggested by Baron \& Kenny (1986) were followed in the mediating analysis. First, the results of the correlation analysis indicated that there is a significant relationship among all the three variables. As indicated in Table 5, organisational culture had a significant relationship with commitment and person organisation-fit, person organisation fit also had a significant relationship with commitment.

Table 5: Correlation Analysis on Organisational Culture, Commitment and Person Organisation-Fit

\begin{tabular}{|l|l|c|c|c|}
\hline \multicolumn{2}{|c|}{} & $\begin{array}{c}\text { Organisational } \\
\text { Culture }\end{array}$ & $\begin{array}{c}\text { Person } \\
\text { Organisation-Fit }\end{array}$ & Commitment \\
\hline \multirow{4}{*}{ Organisational Culture } & Pearson Correlation & 1 & $.450^{* *}$ & $.333^{* *}$ \\
\cline { 2 - 5 } & Sig. (2-tailed) & & .000 & .001 \\
\cline { 2 - 5 } & $\mathrm{N}$ & 104 & 104 & 104 \\
\hline \multirow{4}{*}{ Person Organisation-Fit } & Pearson Correlation & $.450^{* *}$ & 1 & $.201^{*}$ \\
\cline { 2 - 5 } & Sig. (2-tailed) & .000 & 104 & 104 \\
\cline { 2 - 5 } & $\mathrm{N}$ & $.333^{* *}$ & $.201^{*}$ & 1 \\
\hline \multirow{3}{*}{ Commitment } & Pearson Correlation & .001 & .041 & 104 \\
\cline { 2 - 5 } & Sig. (2-tailed) & 104 & & 104 \\
\cline { 2 - 5 } & $\mathrm{N}$ & & \\
\hline \multirow{2}{*}{$* *$ Correlation is significant at the 0.01 level (2-tailed). } & & \\
\hline \multirow{2}{*}{$*$. Correlation is significant at the 0.05 level (2-tailed). }
\end{tabular}

The hierarchical regression was also conducted to investigate the mediating role of organisational culture on person organisation-fit and employee commitment. As shown in Table 6, the step one of the model test for the effect of the independent variable (person organisation-fit) on the dependent variable (commitment) without the mediating variable (organisational culture). The results revealed that there is a significant relationship between person-organisation fit and employee commitment without the mediating variable $(\mathrm{p}<.05)$. However, the relationship between person organisation-fit and commitment became insignificant $(\mathrm{p}>.05)$ when the mediating variable was introduced in the second model (model 2). The result shows that there is a full mediation. This implies that organizational culture mediates between person organization-fit and employee commitment. 
Table 6: Mediation Analysis of organisational Culture on Person Organisation-Fit and Commitment

\begin{tabular}{|c|c|c|c|c|c|c|}
\hline \multicolumn{7}{|c|}{ Coefficient } \\
\hline \multicolumn{2}{|c|}{ Model } & \multicolumn{2}{|c|}{ Unstandardized Coefficients } & \multirow{2}{*}{$\begin{array}{c}\begin{array}{c}\text { Standardized } \\
\text { Coefficients }\end{array} \\
\text { Beta } \\
\end{array}$} & \multirow[t]{2}{*}{$t$} & \multirow[t]{2}{*}{ Sig. } \\
\hline & & $B$ & Std. Error & & & \\
\hline \multirow{2}{*}{1} & (Constant) & .951 & .109 & & 8.748 & .000 \\
\hline & $\mathrm{POF}^{*} \mathrm{EC}$ & .167 & .081 & 201 & 2.069 & .041 \\
\hline \multirow{3}{*}{2} & (Constant) & .645 & .120 & & 5.385 & .000 \\
\hline & $\mathrm{POF}^{*} \mathrm{EC}^{*} \mathrm{OC}$ & .048 & .078 & .057 & .609 & .544 \\
\hline & OC & .363 & .079 & .431 & 4.581 & .000 \\
\hline
\end{tabular}

Table 7: Summary of Hypothesis

\begin{tabular}{|c|l|c|}
\hline Hypothesis & \multicolumn{1}{|c|}{ Statement } & Conclusion \\
\hline H1 & $\begin{array}{l}\text { There is a significant and positive relationship between organisational } \\
\text { culture and employee commitment. }\end{array}$ & Supported \\
\hline H2 & $\begin{array}{l}\text { There is a significant and positive relationship between organizational } \\
\text { culture and person organisation-fit }\end{array}$ & Supported \\
\hline H3 & $\begin{array}{l}\text { Organizational culture mediates the relationship between person } \\
\text { organization-fit and employee commitment. }\end{array}$ & Supported \\
\hline
\end{tabular}

\section{DISCUSSION}

The study revealed that there is a significant and positive relationship between organisational culture and person-organisation fit $(p<.05 ; \beta=.380)$.). The implication is that when the individual values align with that of the organisation, the level of compatibility between the employee and the employer tend to rise. Thus, positive organisational culture is an important determinant of person organisation-fit. The findings of the study confirm other study in other literature. Nazir (2005), indicated that organisational culture is an important factor used to determine how well an employee fits into their organizational context.

Moreover, the study revealed that there is a significant and positive effect between organisational culture and employee commitment $(\mathrm{p}<.05 ; \beta=.337)$. It can be inferred that when there is a high level of organisational culture, employee commitment tends to also increase. When employees feel they are part of the organization, such identification contributes to fostering a high level of commitment and innovation. According to Nongo \& Ikyanyon (2012), organisational culture is either the glue that binds employees to the organization or the wind that blows them away. In this regard, when managers or employers are able to sustain or manage some level of culture in an organisation, employees' positive outcomes such as commitment will arouse. A strong corporate culture enables employees understand the goals of the organization. The drive to the achievement of the organizational goals arouse the commitment level of employees.

The study further revealed that there is a significant relationship between the dependent variable (commitment) and the independent variable (person organisation-fit) without the mediating variable. Person organisation fit significantly predicts employee commitment. However, the introduction of the mediating variable affected the relationship and became insignificant $(\mathrm{p}=.544)$. The results imply a full mediation. Organisational culture fully mediates on person organisation-fit and commitment. This further indicates that organisational culture intervenes in the relationship between person organisation fit and employee commitment. Therefore, organizational culture fully mediates on person organization fit and employee commitment. 


\section{CONCLUSION}

Premising on the analysis and findings of the study, organisational culture is significantly related to person organisation-fit and employee commitment. The study found that organizational culture is an important element which highly influences the employee commitment and person organisation-fit. It is viewed that strong organizational culture is very helpful for the new employees to adopt the organizational values to get the competitive advantage. In the light of the findings of the study, it is recommended that organizational policies regarding culture should be clear to the employees. The flexibility of the culture of an organisation provide a conducive working environment to employees in which they may work easily and independently without feeling any burden. As a result, organization should have a flexible culture and top management should adopt decentralized technique of management to ensure that employees at low level have authority and power to make decision.

\section{References}

Acar, A. Z. (2012). Organizational culture , leadership styles and organizational commitment in Turkish logistics industry. Procedia - Social and Behavioral Sciences, 58, 217-226. https://doi.org/10.1016/j.sbspro.2012.09.995

Ahmadian, N., \& Etebarian, A. (2015). The Effect Of Person-Organization Fit On Work Engagement And Organizational Engagement Case Study: Education Organization Of Char Mahalbakhtiari Province. Indian Journal of Fundamental and Applied Life Sciences, 5(S2), 231-236.

Boon, C., den Hartog, D. N., Boselie, P., \& Paauwe, J. (2011). The relationship between perceptions of HR practices and employee outcomes: Examining the role of person-organisation and person-job fit. International Journal of Human Resource Management, 22(1), 138-162. https://doi.org/10.1080/09585192.2011.538978

Clugston, M. (2000). The mediating e ects of multidimensional commitment on job satisfaction and intent to leave. Journal of Organisational Behaviour, 21, 477-486.

Ćulibrk, J., Delić, M., Mitrović, S., \& Ćulibrk, D. (2018). Job satisfaction, organizational commitment and job involvement: The mediating role of job involvement. Frontiers in Psychology, 9(132), 1-12. https://doi.org/10.3389/fpsyg.2018.00132

Dwinfour, E. A. S., Adam, S., \& Adom, D. (2017). The Effects of Organizational Culture and Commitment on Job Satisfaction : Cross-Sectorial Comparison of Legal Services Sector in Ghana. European Journal of Business and Management, 9(14), 29-35.

Gray, J. H., Densten, I. L., \& Sarros, J. C. (2003). Size Matters : Organisational Culture in Small , Medium , and Large Australian Organisations. Journal of Small Business \& Entrepreneurship, 17(1), 31-46. https://doi.org/10.1080/08276331.2003.10593311

Habib, S., Aslam, S., Hussain, A., Yasmeen, S., \& Ibrahim, M. (2014). The Impact of Organizational Culture on Job Satisfaction , Employess Commitment and Turn over Intention. Advances in Economics and Business, 2(6), 215222. https://doi.org/10.13189/aeb.2014.020601

Hafiz, A. (2017). Relationship between Organizational Commitment and Employeeâs Performance Evidence from Banking Sector of Lahore. Arabian Journal of Business and Management Review, 7(2), 1-7. https://doi.org/10.4172/2223-5833.1000304

Harris, S. G., \& Mossholder, K. W. (1996). The affective implications of perceived congruence with culture dimensions during organizational transformation. Journal of Management, 22(4), 527-547. https://doi.org/10.1016/S0149-2063(96)90023-9

Janićijević, N. (2015). Impact of Organizational Culture on Organizational Learning and Knowledge Management. Proceedings of the ENTRENOVA - ENTerprise REsearch InNOVAtion Conference, 158-165. Kotor, Montengero.

Karakurum, Mü. (2005). The Effects Of Person-Organization Fit On Employee Job Satisfaction, Performance And Organizational Commitment In A Turkish Public Organization. Middle East Technical University.

Kline, R. B. (2011). Principles and Practice of Structural Equation Modeling (Third Edit; D. A. Kenny \& T. D. Little, Eds.). New York London: THE GUILFORD PRESS.

Kristof-Brown, A. L., Zimmerman, R. D., \& Johnson, E. C. (2005). Consequences of individuals' fit at work: Personorganization , person-group , and person-supervisor fit. Personnel Psychology, 58, 281-342.

https://doi.org/10.1111/j.1744-6570.2005.00672.x 
Latif, A., \& Bashir, U. (2013). Person organization fit, job satisfaction and turnover intention : An empirical study in the context of Pakistan. Global Advanced Research Journal of Management and Business Studies, 2(7), 384-388.

Lau, H. C., \& Idris, M. A. (2001). The soft foundation of the critical success factors on TQM implementation in Malaysia. The TQM Magazine, 13(1), 51-60.

Lok, P., \& Crawford, J. (2001). Antecedents of organizational commitment and the mediating role of job satisfaction. Journal of Managerial Psychology, 16(8), 594-613.

Lund, D. B. (2003). Organisational Culture and Job Satisfaction. Journal of Business and Industrial Marketing, 18(3), 219-236. https://doi.org/10.13703/j.0255-2930.2016.10.007

Meyer, J. P., Stanley, D. J., Herscovitch, L., \& Topolnytsky, L. (2002). Affective , Continuance , and Normative Commitment to the Organization : A Meta-analysis of Antecedents , Correlates , and Consequences. Journal of Vocational Behavior, 61, 20-52. https://doi.org/10.1006/jvbe.2001.1842

Muthuvelo, R., \& Che Rose, R. (2005). Typology of Organisational Commitment. American Journal of Applied Sciences, 2(6), 1078-1081. https://doi.org/10.3844/ajassp.2005.1078.1081

Narayana, A. (2017). A Critical Review of Organizational Culture on Employee Performance. American Journal of Engineering and Technology Management, 2(5), 72-76. https://doi.org/10.11648/j.ajetm.20170205.13

Nazir, N. A. (2005). Person-Culture Fit and Employee Commitment in Banks. VIKALPA, 30(3), 39-51.

Nongo, E. S., \& Ikyanyon, D. N. (2012). The Influence of Corporate Culture on Employee Commitment to the Organization. International Journal of Business and Management, 7(22), 21-28.

https://doi.org/10.5539/ijbm.v7n22p21

Ongori, H. (2007). A review of the literature on employee empowerment. African Journal of Business Management, 5(4), 49-54. https://doi.org/10.1108/14634449710195471

Ostroff, C., Shin, Y., \& Kinicki, A. J. (2005). Multiple perspectives of congruence: Relationships between value congruence and employee attitudes. Journal of Organizational Behavior, 26(6), 591-623.

https://doi.org/10.1002/job.333

Quratulain, S., Khan, A. K., Crawshaw, J. R., Arain, G. A., \& Hameed, I. (2018). A study of employee affective organizational commitment and retention in Pakistan: the roles of psychological contract breach and norms of reciprocity. International Journal of Human Resource Management, 29(17), 2552-2579.

https://doi.org/10.1080/09585192.2016.1254099

Rastegar, A. A., \& Aghayan, S. (2012). Impacts Of Organizational Culture On Organizational Commitment. Journal of Human Resource Management, 2(2), 1-13.

Sabir, M. S., Razzaq, A., \& Yameen, M. (2010). Impact of Organizational Culture on the Employees' Commitment: Relationship between Levels of Organizational Culture with Commitment. KASBIT Business Journal, 3(1), 88-95.

Samudi, S., Slambolchi, A., \& Mobarakabadi, H. (2016). A Literature Review On Organizational Commitment : A Comprehensive Summary. Applied Mathematics in Engineering, Management and Technology, 4(3), 47-57.

Schein, E. . (2010). Chapter 2 - The three levels of culture. In Business and Management: Organizational Culture and Leadership (Fourth Edi, pp. 23-33). Retrieved from http://my.safaribooksonline.com/book/leadership/9780470190609

Sharma, A., \& Singh, S. (2017). Impact of Organizational Culture on Employee Commitment: A Comparative Study of Public and Private Sector Telecom Companies in India. International Journal of Engineering Technology Science and Research IJETSR, 4(12), 721-727.

Silverthorne, C. (2004). The impact of organizational culture and person-organization fit on organizational commitment and job satisfaction in Taiwan. The Leadership \& Organization Development Journal, 25(7), 592-599. https://doi.org/10.1108/01437730410561477

Sutarjo. (2011). Ten Ways of Managing Person-Organization Fit ( P-O Fit ) Effectively : A Literature. International Journal of Business and Social Science, 2(21), 226-233.

Ullman, J. B., \& Bentler, P. M. (1998). Structural Equation Modeling. In I. B. Weiner (Ed.), Handbook of Psychology (Second Edi, pp. 661-689). Retrieved from http://onlinelibrary.wiley.com/doi/10.1002/0470011815.b2a13089/full 
Verquer, M. L., Beehr, T. A., \& Wagner, S. H. (2003). A meta-analysis of relations between person-organization fit and work attitudes. Journal of Vocational Behavior, 63, 473-489. https://doi.org/10.1016/S0001-8791(02)000362

Wasti, S. A. (2003). Organizational commitment, turnover intentions and the in uence of cultural values. Journal of Occupational and Organizational Psychology, 76, 303-321.

Wheeler, A. R., Gallagher, V. C., Brouer, R. L., \& Sablynski, C. J. (2007). When person-organization (mis) fit and (dis) satisfaction lead to turnover: The moderating role of perceived job mobility. Journal of Managerial Psychology, 22(2), 203-219. https://doi.org/10.1108/02683940710726447 